○山下恒夫 · 小石幸生

〔目的〕最近, 変形性膝関節症の訬断に Rosenberg ら が提唱した立位膝屈曲 45 度の膝関節正面 X線撮影が利用 されている。われわれは, 本法に ORBIX 撮影装置の使用 も試み㯟の屈曲角度 $(30,45,60$ 度と変化）やX線の入 射角度などについて検討を行い臨床評価を加えたので報 告する。

〔結果〕 (1)関節間隙を広く描出するには，X線の入射 角度は滕の屈曲角度30度において頭尾方向 5 度, 45度に おいて同10度，また60度においては同20度が最適であっ た. (2)関節面状態の描出能（病巣の発見率）については 膝屈曲45度の場合が最善であった. (3) ORBIX 撮影装置 の使用により，斜入のない高画質の写真が得られ，また 簡単にX線の入射角度が変えられ，撮影自体も容易であ った.

\section{4. 腹部・骨盤部側面撮影用補償フィルタ}

九州大学医学部付属病院放射線部 中村善郎

〔目的〕上記撮影は撮影条件が大となり，均一なフィ ルム濃度を得ることが困難である．腰椎棘突起および， 体表面の軟部組織も観察できる濃度補償を目的として製 作した

〔方法】腹部および骨盤部側面 X線フィルムを参考に， 腹部は 3 種類 (肥満, やせ，胸部突出タイプ)，骨盤部 1 種類に大別し計 4 組のフィルタを製作した。

フィルタ材質：Al $20 \mathrm{~mm}$ ，スロープ角度 $20 / 30 \mathrm{~mm}$

〔結果〕各患者さんの体型にマッチした濃度補償が得 られ黒くて観察できない部位がなくなったため，診断域 が広くなり観察者に安心感を与える。

15. 当院のマンモグラフィ増感紙一フィルム特性と問題 点

\section{国立熊本病院 \\ 文字洋一・河上勝美・荒木不次男 小崎一宏・河野 孟}

当院では，マンモグラフィに使用していた増感紙が劣 化したためと被ばく線量減少を図るために感度の高いマ ンモグラフィ専用の増感紙-フィルムの組み合わせを比 較検討した．また年齢別構成の分析，超音波検査との画 像比較を行った。その結果，F社の増感紙一フィルムの組 み合わせが，高感度でありながら良好な分解能を有し， 被ばく線量も減少することができた，年歯別構成は20代 と30代の合計が最も多くなり，発達した乳腺への被ばく 線量が問題となる.またこのような患者の撮影扔よび読 影も困難となる，超音波検查は，結節状陰影の描出に優 れているが，微小石灰化像や乳腺全体像を描出するには，
マンモグラフィが有利であった。

\section{座長集約}

演題12は MTF 值より臨床写真の検討をしている．結 果的には拡大ボケとクロスオーバ効果の影響であり $\mathrm{FFD} 65 \mathrm{~cm}$ と短くとることにより，観察しやすくなっ ている.との報告であるが皮ふ表面線量も1.7倍に増加し ている点が気になるところである。

今後は, MTF だけでなく, 他の因子も考慮し検討を加 えてほしい。

演題13はローゼバーグらが提唱した㯟関節正面撮影法 をORBIX を使用することによって, 1.5倍拡大撮影を容 易にし，かつ，クロスオーバ効果による画質の低下を防 ぐことができるため，診断上有用であるとしている。

質問 （長田 長崎）X線入射角の決定方法は?

答 屈曲角を45度にした場合, 垂直に対して下腿側で 22.5 度，大腿側でも22.5度になるように設定し入射角を 決定する。

質問（座長） 体位保持のために特別な補助具など は?

答 手を支えるための支柱があるが，特別なものはな い. 演題14は腰部，骨盤側面の濃度補償フィルタについ ての報告である。

画像の診断域を広げ，被曝線量を低減するというテー マに独自の創意工夫をしているところに意義があると思 う。しかし，経験に頼るだけでなく科学的に，材質の選 択や感材なども含めて検討を加えるべきであろう。

質問 (高知 大分) (1)フィルタの材質に Al を使用 した理由は (2)挿入位置の決定方法は

答 塩化ビニールは，吸収効率が悪く，加工しにくく エッジがシャープにできないため，アーチファクトが出 やすいため，Alにした。

(2) 経験的に挿入している.

演題15は乳腺撮影の感材についての検討と，6年間に 渡る超音波と乳腺撮影との診断能の比較検討である.

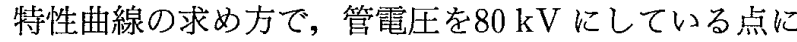
疑問が残る。

質問（広渡 福岡） 乳腺撮影に CR の導入を考えて いるというが，超音波と一般の乳腺撮影で充分ではない だろうか。

答 特に若年者の腺性乳腺の描出には CR が有用では ないかと考えている。

質問（畑田 福岡）超音波の方が乳線撮影の画像よ り診断能が高いというデータがでている，私共の施設で は差異は認められないが，圧迫撮影はおこなっているの 
か.

答 装置の操作性が悪いため, 圧迫はやっていない, 不足分（情報の）は，両斜位で補っている。

専用機器の導入を予定している.

\section{放射線管理}

座長 泉 隆（九州大学医学部附属病院）

16. 新医療法施行規則による $X$ 線診療室の遮蔽計算につ いて

\section{九州大学医学部附属病院放射線部}

○橘 昌幸・泉隆・穴井重男 重谷 昇

平成元年 4 月より医療法施行規則が改正・施行され, これに伴いX線診療室の遮蔽計算方法が全く新しいもの となった。 そこで 1 利用線錐方向が一方向のみの場合 2 一室にX線管が 2 つ以上ある場合 3 透視撮影室の場合 4 $\mathrm{CT}$ 撮影室の場合について遮蔽計算を行い，1の場合実 際には存在するX線管からの利用線錐方向への漏浅線を 考慮していない 2 の場合, 具体的な計算方法がない 30 場合, 透視管電圧と撮影管電圧が異なる場合の計算方法 がわからない 4 の場合具体的な計算方法がない，などの 問題点があり，厚生省などに問い合わせをしたが明確な 解答が得られず, 技術学会などで遮蔽計算方法を検討し ていくことの必要性を感じた.

\section{7. 重複フィルムバッジ着用時の問題点と产の評価}

日本赤十字社長崎原爆病院

大町繁美・一瀬圭二・宮本憲一

高橋 朗

〔目的〕医療法施行規則が改正され，血管造影や胃腸 透視などの不均等被懪時には，男性は胸部，女性は腹部 以外に頭頸部（プロテクターから露出している部位）に もフィルムバッジを着用する必要性が出てきた。今回, オーバチュブ型（血管造影用）とアンダーチュブ型（消 化器透視用）を設置している透視室のベッドに対して水 平方向と垂直方向の室内散乱線分布図を作製し, 散乱線 の分布状態を知ることにより，フィルムバッジ着用時の 実用上の問題点を取り上げ，放射線防護を考える。

〔考察〕 透視中の散乱線分布は肩幅ぐらいの距離でも 急激な変化を示し, 検査の種類, 術者の立つ位置によっ て評価が変わる，散乱線分布を把握し，着用の仕方を考 光た.

18. I.I. 性能検査時の目の被曝線量（医用装置管理第18 報）

九州大学医学部付属病院放射線部 中村善郎

〔目的〕当放射線部において, I.I. 性能検査時, I.I. 出
力面を裸眼直視で行う検查項目は， 1 輝度むら，污点， 2 フラッシュ, ストレー, 像の拡動, 3 歪, 4 残光, 5 コントラスト， 6 解像度の 6 項目である. 各項目の裸眼 直視時間を 60 秒と想定し，この時の目の被懪線量を測定 した.

〔方法〕I.I. 出力面レンズに TLD 3 本を貼付し, 当放 射線部検収マニュアルに定めた照射条件で各項目に照射 しこの時の積算線量を測定した。

〔結果〕I.I.に入射したX線はそのほとんどが先に変 換され，もしくは出力面レンズに吸収され，目の被嚗線 量は皆無に近いことが明らかになった。

19. パノラマX線断層撮影における被曝線量の低減 九州大学歯学部附属病院

川下一浩・加藤 誠・松尾利明 パノラマX線断層撮影装置は, 多軌道化, $\mathrm{CR}$ 対応, 診 断領域の拡大などにより 4 切，パノラマサイズ兼用型が 普及しつつある. 当院で使用している AUTO-1000もこ のタイプであるが，目的に応じた絞り機構はなく常に同 一ビーム幅（4 切サイズ）で照射される，そこで今回わ れわれは, 通常のデンタルアーチ撮影に必要十分な, フ ィルム上でのX線ビームの縦幅をパノラマサイズに絞り， 顔面領域主要藏器での被曝線量を絞らない場合と比較し た. その結果, 絞りを設けることにより耳下腺部，顎下 腺部，甲状腺部で 5 〜 $10 \%$, 水晶体部で約 $50 \%$ の減少が 得られた。 よってパノラマ装置は, 撮影目的別, 患者サ イズ別で調節可能な絞り機構が必要である.

\section{0．RI 投与患者の被曝量の検討}

久留米大学病院中央放射線部

○河村誠治・白石嘉孝・蓑原 享 久留米大学医学部放射性同位元素施設 梅崎典良 久留米大学医学部放射線医学教室 石橋正敏・森田誠一郎

${ }^{99 \mathrm{~m}} \mathrm{Tc}-\mathrm{MDP}$ 投与患者の尿中の放射能を測定すること により膀腅壁被嚗量の低減策について検討したので報告 する. RI 投与患者の排尿ごとの放射能をキュリーメータ で測定した. 平均の排尿間隔は約 2 時間であった。第 1 回目の排尿で投与放射能の約 $50 \%$ が排泄され，2 回目の 排泄で投与放射能の $10 \%$ 以下が排泄された。この結果を 指数関数を用いて数式化した。数式を用いて Mird 法に より初回排尿時間と膀胱壁被曝量との関係を求めた。膀 胱壁被曝量が最小になる被回排尿時間は約50分であった。 その時の被曝量は RI 投与後初回排尿を 2 時間とした時 を100とすると約60であり，現状の膀胱壁被曝量を約 $40 \%$ 低減できると推定された。 